\title{
The Russian-speakers in the CIS countries: migration activity and preservation of the Russian language
}

\author{
Svetlana Maximova ${ }^{1}$, Oksana Noyanzina $^{1, *}$, Daria Omelchenko $^{1}$, and Margarita \\ Maximova $^{1}$ \\ ${ }^{1}$ Altai State University, 656049, Lenin ave., 61, Barnaul, Russia
}

\begin{abstract}
The purpose of this article is to analyze migration activity in the post-Soviet space, changes in ethnic composition in the CIS countries and their role in peculiarities of preservation, functioning and representations about the Russian language, its main characteristics and proficiency among population from CIS countries. Empirical data was collected during the sociological research, fulfilled in 2017 in six countries members of the Commonwealth of Independent States (CIS): Armenia, Belarus, Kazakhstan, Kyrgyzstan, Moldova, Tajikistan, $n=1400$. Informationgathering methods included formal interviews in the place of residence of population aged 18 to 75 years. Several indicators were used to achieve the goal: representations about the Russian language; assessment of the role of the Russian language; main characteristics of the Russian language; Russian language proficiency. The article states that in considering principal peculiarities of functioning of Russian in the post-Soviet space demographic indicators such as number of population, number of ethnic groups, proportion of Russian and indigenous population in CIS countries, changes in number of Russians after the dissolution of the USSR, external migration indicators should be taken into account. It was concluded that the Russian language proficiency is important for its preservation and functioning on the territory of CIS countries, the Russian language is well preserved in Belarus, at the middle level in Armenia, Kazakhstan, Kyrgyzstan, Moldova and at the lowest level in Tajikistan. The popularity of Russian in respondents' evaluations is determined by non-linguistic factors and characteristics, and associated with successful foreign policy of Russia and development of economic and trade relations of Russia with other countries. The development of the tourist sector and attractiveness of Russia for immigration are significant catalysts of interest towards the Russian language, influence of targeted programs, aimed at enhancing the positions of the Russian language and popularization of the Russian culture estimated as less significant. Attractiveness of Russia for immigration, increase of migration streams are important incentives for development and preservation of the Russian language.
\end{abstract}

* Corresponding author: noe @ list.ru 


\section{Introduction}

International migration is a global phenomenon, having a great influence for separate countries, regions, and the world community. It penetrates of countries of the world, turning countries from separate states to countries of entry, exit and transit of international migrants, changing their economic, cultural bases and social structures.

Contemporary researches list higher level of life, opportunities of employment and material support of families among general attracting factors [1], as well as provision of personal security and access to education [2]. Among pushing factor are poverty and absence of food security [3], political instability, absence in investment into transport, agriculture and energy infrastructure, unemployment [4] social development: the more developed countries attract migrants from the less developed countries. In this, De Haas argues about interaction between the migration and development of non-linear character, it is built-in social, political and economic contexts, which have no explicit - positive or negative - influence [5]. Besides, investments into economy of the developing countries may affect the intensity of migration streams only in long-term perspective [6].

Thus, the estimation of migration situation at the post-Soviet space is impossible without understanding the history about new independent states, which recently were pars of the one state, and migration had in-country character [7]. Common historical roots emerged in a result of numerous personal and relative networks between inhabitants of different states, common cultural codes, keeping of unite language space, although considerably reduced, and wide diaspora of representative of nations, originating from the other parts of the former USSR [8]

Russian language as an element of identity and communication resource, which unites citizens of Russia, countries of the former Soviet countries, and far abroad, plays considerable role in the statement of contemporary political, economic and educational dialogue. It is native language for more than 168 million of people; more than 114 million of people are fluent in the Russian as the second native (in the CIS and the Baltic countries dominantly) or speak Russian as the foreign one (in countries of the far abroad). The strengthening of positions of the Russian language is a strategic national priority of the Russian Federation.

However, despite evident success in keeping Russian, the context of dynamics of the last decades out to the agenda questions connected with negative evaluations of the role of the Russian language. At the post-Soviet space, the Russian language 'stop to be natural language environment'. Generation, fluent in Russian in the CIS countries slowly leaves. Keep to be strong such worrying tendencies as the lowering of Russian language presence, reducing of the number of Russian schools abroad, their poor equipment and support, reducing the number of pupils who learn Russian in the systems of secondary and higher education (in the CIS countries, first of all), reducing in numbers of the teachers of Russian, and lowering the level of their professional competences.

The paper of the Ministry of Internal Affairs of the Russian Federation 'Russian language in the world' points out the 'problem of giving of a special status to the Russian language as the primordial one. It the key factor of keeping its positions' [9].

In the Byelorussia, the Russian language has the state status, such as the Byelorussian one. In the Kirgizia, the Russian language is obligatory in governmental bodies and local authorities. According to the Kazakhstan Constitution, the state language is the Kazakh one. In legislation, status of the Russian language was enhanced in 1995, now at can be 'officially used in addition with the Kazakh one in governmental organizations and local bodies'. The right for functioning of the Russian language is determined by the Moldova Republic Constitution (article 13, point 2) and regulated by the Law about the function of languages at the territory of the Moldova Republic of 1994. The law guarantees 'the right 
for citizens for elementary, secondary, secondary technical, and higher education in Russian and right to use it in relation with governmental bodies'. Now there is discussion about the state status of the Russian.

According to the Tajikistan Constitution, the state language is the Tajik one, the Russian - is a language of interethnic relations. The status of the Russian language in the Azerbaijan is not regulated in the legislations. In the Armenia, the Georgia, and the Uzbekistan Russian is the language of national minority. In the Ukraine, only the status of the Ukrainian language is fixed in the Constitution [9].

The purpose of the paper is in the evaluation of migration activity at the post-Soviet space, changes of ethnic composition in the CIS countries and their role in peculiarities of preservation and functioning of the Russian language, level of knowledge of the Russian at the post-Soviet space.

\section{Methods}

The empirical base of the article are the data of sociological research in 2017 at the territory of six countries, participants of the CIS $(n=1400)$. After the data cleaning, we included information by 1326 respondents, residing the CIS countries: The Armenia Republic ( $\mathrm{n}=$ 121), the Byelorussia Republic $(\mathrm{n}=224)$, the Kazakhstan Republic $(\mathrm{n}=258)$, the Kyrgyzstan Republic $(n=245)$, The Moldova Republic $(n=205)$, and the Tajikistan Republic $(\mathrm{n}=122)$.

Describing the country of origin of respondents, our respondents in most numbers were native-born inhabitants of republics, i.e. answering the question: 'In which country were you born?' they indicated the present country of residence. Thus, in the Armenia $69.4 \%$ indicated the Armenia, in the Byelorussia 93.2\% - the Byelorussia, in the Kazakhstan 96.8\% - the Kazakhstan, in the Kirgizia 97.9\% - the Kirgizia, in the Moldova 95.1\% - the Moldova, and in the Tajikistan $100 \%$ - the Tajikistan.

Among respondents were $41.3 \%$ of men and $58.7 \%$ of women and the average age of 28 years: at the age under $19-31.4 \%$, young people at the age from 20 to $29-36.9 \%$, at the age from 30 to $49-25.5 \%$, 50 years and older $-6.2 \%$. More than the third part of respondents consider themselves as citizens of county of residence $(41.5 \%)$, first. The others identify themselves as representatives of ethnic groups $(23.6 \%)$ or the cosmopolites (i.e. have global identity, 16\%), Only $8.2 \%$ identify themselves as the Eastern people, inhabitants of concrete region or settlement (3.3\% and 3\% correspondingly).

Method of data collecting: formalized interview in households among population at the age from 18 to 75 . To base the statistical conclusion we used the corresponding to the data nature (nominative or quantitative) statistical methods of dispersion analysis with the use of the SPSS data package.

To achieve the goal of the paper we used the following variables:

- Representations about Russian language and evaluation of the role of Russian language (on the base of distribution of answers the question: 'What are, in your opinion, the most important characteristics of the Russian language: language of an international communication and integrational integration; language for uniting of all the Russianspeaking in the world; language-mediator, distributed around Russia and the former Socialist block; one of the life languages with a lot of speakers and rich cultural traditions; language of labor migration to Russia; very hard to learn and pronounce; beautiful, rich in expressive possibilities, melodically language; language, which are not able to compete world other world languages (English, Chinese, and so on); one of the leading languages of the world artistic culture; language, loosing own position at the world arena');

- Level of language skills in Russian (on the base of distribution of answers the questions: 'What is the Russian language for you?'; 'Which language did you learn in 
childhood and still understand?; 'Which language do you speak in family?'; 'Which language do you speak in public spaces?; 'How proficient you are in Russian?').

\section{Results and discussion}

\subsection{Social context of the functioning of the Russian}

Considering general aspects of the functioning of the Russian language at the post-Soviet space, it is necessary to take into account demographic indexes, especially: number of population, ethnic composition, correlation between aboriginal and Russian population of the CIS countries, change in numbers of Russians after the Soviet Union's collapse, and indexes of external migration of population.

The given positions became the base for analysis of the number of the Russians and other aboriginal ethnos of Russia, living in the former Soviet republics. We may obtain quantitative indexes only if relying on the population census data and correlating official information about all former Soviet republics (characteristic to the stage of census of 2000). National census of the 2009+ stages were realized at various periods at the post-Soviet space. According to official data, census in the Azerbaijan occurred in 2009, in the Armenia - in 2011, in the Byelorussia - in 2010, in the Georgia - in 2011, in the Kazakhstan - 2009, in the Kirgizia - in 2009, in the Moldova - in 2014, in the Tajikistan - in 2010, in Turkmenistan - in 2012, in the Uzbekistan - in 2010, in the Ukraine - in 2011, in the Lithuania - in 2011, in Latvia - in 2011, in the Estonia - in 2012, in Russia - in 2010.

As for statistics of ethnic composition of the newly independent states, by data of 2000 stage of census, the number of Russians in the CIS and the Baltic countries consisted about 17.8 millions of people that 3.8 millions higher than in data of the 2009+ census (table 1).

Results of the last stage of census let to conclude about the process of continuing reduction of the Russian diaspora at the post-Soviet area during last decades, but its pace reduced too. Thus, in the Kazakhstan for the period of 2000 the number of Russians reduced for 686 thousands of people (15\%), whereas in 1990s - for 1582 thousands of people $(26 \%)$. The same is in the Azerbaijan, the Kirgizia, and the Lithuania. The paces of reeducation continue of keep in Latvia and Estonia. In the Byelorussia the situation is opposite. In 1989 about 1342 thousands of Russians lived in the Byelorussia, in 1999 1142 thousands of people (200 thousands less), in 2009 - 785 thousands of Russians (more than 350 thousands less) [10]. However, this conditioned not only by the processes of reproduction and migration, but also by the change of ethnic self-identification of Russians during census [11].

Table 1. Number of Russians at the post-Soviet space [12].

\begin{tabular}{|c|c|c|c|c|}
\hline Country & $\begin{array}{c}\text { Number of } \\
\text { Russians, } \\
\text { thousands of } \\
\text { people } \\
\text { Data of the } \\
2000 \text { census }\end{array}$ & $\begin{array}{c}\text { Part of Russians } \\
\text { census } 2000\end{array}$ & $\begin{array}{c}\text { Number of } \\
\text { Russians, } \\
\text { thousands of } \\
\text { people } \\
\text { Data of the } \\
2009+\text { census }\end{array}$ & Part of Russians \\
Data of the \\
$2009+$ census \\
\hline Azerbaijan & 142 & 1.6 & 119.3 & 1.3 \\
\hline Armenia & 15 & 0.5 & 11.9 & 0.39 \\
\hline Byelorussia & 1142 & 11.6 & 785 & 8.26 \\
\hline Georgia & 68 & 1.4 & 26.4 & 1.0 \\
\hline Kazakhstan & 4480 & 29.4 & 3794 & 24.5 \\
\hline Kyrgyzstan & 603 & 11.7 & 419.6 & 7.8 \\
\hline Moldova & 201 & 5.9 & 111.7 & 4.1 \\
\hline
\end{tabular}




\begin{tabular}{|c|c|c|c|c|}
\hline Tajikistan & 68 & 0.9 & 35 & 0.5 \\
\hline Turkmenistan & 299 & 6 & 165 & $2.7^{*}$ \\
\hline Uzbekistan & 1092 & 4 & 80.9 & 2.5 \\
\hline Ukraine & 8334 & 17.9 & 7400 & 16.2 \\
\hline Lithuania & 220 & 6.3 & 162 & 5.4 \\
\hline Latvia & 720 & 31.7 & 506 & 26.9 \\
\hline Estonia & 406 & 30.6 & 321 & 25.4 \\
\hline $\begin{array}{c}\text { Total Russians in } \\
\text { the CIS and Baltic } \\
\text { countries }\end{array}$ & 17790 & - & 13937.8 & - \\
\hline Russia & 115889 & 80.6 & 111016 & 80.9 \\
\hline
\end{tabular}

* Assessment data of the Turkmenistan State Committee on Statistics, 2012.

According to national population census, the total number of Russians in the former Soviet republics at present dos not exceed 13.9 millions of people. As Rysazantsev and Grebenyuk consider, a part of Russians together with other Russian aboriginal ethnic form migration potential of the Russia with the use of proper migration policy, further socialeconomic development, and stable internal political situation.

\subsection{Social representations about functioning of the Russian language at the post-Soviet space}

Russian language is a language with a special status in international diplomacy, business, cultural and sport events, and creation of the world masterpieces of artistic literature. Many the CIS inhabitants learned Russian in the times of the USSR, that Russian language was the state and obligatory one for all citizens of the Union's republics. Nowadays Russian does not have such importance for the young generations such it was during the Soviet government. However, representations and relation to the Russian language naturally differ from the other world countries with taking into consideration family networks and experience of elderly generation with natural fluency in Russian, boundary condition and special conditions for the entry into Russia.

The realized research studied representation about Russian language, its general characteristics and level of knowledge at the post-Soviet space.

As for the most important characteristics of the Russian language, 54.3\% of respondents consider the Russian as a language of the world artistic culture - literature, cinema, theater and so on, $52.9 \%$ - as one of the most required languages, uniting the Russian-speaking people all over the world, $36.1 \%$ - as one of the most important factors, uniting interethnic population of Russia, 36\% consider the Russian as one of the leading world languages and official language of international organizations.

The other variants of the questions were marked less by the third part of respondents. Thus, $22.1 \%$ of the research participants noted that the Russian occupied leading positions at the market of educational services, $12.8 \%$ - is a language of the science and technological achievements.

The majority of the CIS citizens consider that 'Russian language is one of the most required languages, uniting the Russian-speakers in the world', as testify $59 \%$ residents of the Armenia, 53\% - of the Byelorussia, 49.2\% - of the Kazakhstan, 54.8\% - of the Kirgizia, 55.4\% - of the Moldova, and 44.9\% - of the Tajikistan.

Underlying, the CIS representatives highly evaluate the role of Russian language as 'a language of the world artistic culture - literature, arts, theater, and ballet', such as $67.3 \%$ of the Moldova respondents, $60 \%$ - of the Byelorussia. 
Population of the Tajikistan Republic (51.7\%) and the Kyrgyzstan Republic (40.9\%) mark the role of the Russian as 'a one of the world leading languages of international organizations, high-level meetings'.

As for the Tajikistan citizens, $38.1 \%$ of them testify that the Russian language occupies the leading positions at the educational market and let to get a higher professional education for the Tajiks. Objectively, a huge number of Tajik students studying in Russian higher educational institutions.

Population of the CIS countries speaks about the Russian language as one of the important factors, uniting interethnic Russian population, as mark $47.9 \%$ of the Armenia citizens and $44.6 \%$ - of the Moldova. The Byelorussians marked out that the Russian is the state language $(48.8 \%)$ (table 2).

Table 2. Evaluation of the Russian language by the CIS representatives, $\%$.

\begin{tabular}{|c|c|c|c|c|c|c|}
\hline & \multicolumn{6}{|c|}{ The CIS countries } \\
\hline & Armenia & Byelorussia & Kazakhstan & Kyrgyzstan & Moldova & Tajikistan \\
\hline $\begin{array}{l}\text { Russian - first of all } \\
\text { is the language of } \\
\text { the world artistic } \\
\text { culture - literature, } \\
\text { arts, theater, ballet, } \\
\text { and so on }\end{array}$ & $49.6 \%$ & $60.0 \%$ & $59.3 \%$ & $43.0 \%$ & $67.3 \%$ & $37.3 \%$ \\
\hline $\begin{array}{l}\text { Russian - one of the } \\
\text { leading world } \\
\text { languages, official } \\
\text { language of } \\
\text { international } \\
\text { organizations, high- } \\
\text { level meetings }\end{array}$ & $24.8 \%$ & $23.3 \%$ & $39.4 \%$ & $40.9 \%$ & $36.1 \%$ & $51.7 \%$ \\
\hline $\begin{array}{l}\text { Russian-one of the } \\
\text { most required } \\
\text { languages, uniting } \\
\text { all the Russian- } \\
\text { speakers of the } \\
\text { world }\end{array}$ & $59.0 \%$ & $53.0 \%$ & $49.2 \%$ & $54.8 \%$ & $55.4 \%$ & $44.9 \%$ \\
\hline $\begin{array}{l}\text { Russian occupies } \\
\text { the leading } \\
\text { positions at } \\
\text { international } \\
\text { education market } \\
\text { and let to get higher } \\
\text { professional } \\
\text { education }\end{array}$ & $22.2 \%$ & $7.0 \%$ & $28.5 \%$ & $28.3 \%$ & $16.8 \%$ & $38.1 \%$ \\
\hline $\begin{array}{l}\text { Russian - is the } \\
\text { state language }\end{array}$ & $18.8 \%$ & $48.8 \%$ & $9.8 \%$ & $8.3 \%$ & $6.9 \%$ & $22.0 \%$ \\
\hline $\begin{array}{l}\text { Russian - is one of } \\
\text { the important } \\
\text { uniting factors for } \\
\text { interethnic } \\
\text { populations of } \\
\text { Russia }\end{array}$ & $47.9 \%$ & $36.7 \%$ & $34.6 \%$ & $26.1 \%$ & $44.6 \%$ & $36.4 \%$ \\
\hline $\begin{array}{l}\text { Russian - is a } \\
\text { language of the } \\
\text { science and } \\
\text { technical } \\
\text { achievements }\end{array}$ & $5.1 \%$ & $4.2 \%$ & $19.5 \%$ & $14.8 \%$ & $14.4 \%$ & $16.1 \%$ \\
\hline
\end{tabular}


About one percent of respondents (23 persons) suggested own variant of the answer, stressing the beauty and richness of the Russian ('beautiful language', 'mighty, diverse, and rich language', 'the most beautiful language with lot of adjectives, expressing emotions'), a special status of the Russian in countries with considerable part of the Russians, former Socialist block countries, and bordering with Russia countries ('Russian for the Russians', 'the most spread among the Russian-speaking peoples', 'important regional language', 'the Russian is required at the CIS territories', 'language of the former USSR and the present CIS', 'language of the neighboring country'), a special relation to the Russian language as own native language ('my native language', 'I speak Russian', 'I got used to speak Russian from the childhood', 'language I learn in the childhood'), difficulties in the studying Russian ('too hard for foreigners'), accent at the communicative function of the language ('it is the way of communication, first of all', 'language to communicate with Russian girls'), stylistic peculiarities ('skills in fighting'), absence of any special characteristics ('language as language'), and also the identification of language with the Russian Federation, negatively perceived in a result of its internal policy ('Russian - is the language of the enemy country', 'the language of the alien (unfriendly) state').

As for the own relation to the Russian, $22.3 \%$ of respondents speak Russian as the 'only native language'; $62.7 \%$ - consider it second native (the first is ethnic language), $11.1 \%$ of respondents, living outside the Russian Federation, speak Russian as the foreign one.

Differentiating by countries, $40.2 \%$ of respondents in the Kazakhstan Republic, $25.6 \%$ in the Republic of Byelorussia, and $24 \%$ of the Moldova Russian language is the only native language.

Russian is the second after national language for $79.9 \%$ inhabitants of the Kyrgyzstan, $72.6 \%$ - of the Armenia, 71.2\% - of the Tajikistan and for $65.3 \%$ of the Byelorussia (Fig. 1).

Noting that $27.9 \%$ of the Moldova citizens and $23.7 \%$ of the Tajikistan citizens speak Russian as foreign. At present, there is the objective situation, caused by active outflow from the given countries (Tajikistan and Moldova) of the Russian-speaking population, reducing of schools with education in Russian. In the given courtiers, the Russian language starts to lose its positions as a language of international communications that actualize the necessity to realize active work on promotion and preservation of the Russian in the given countries.

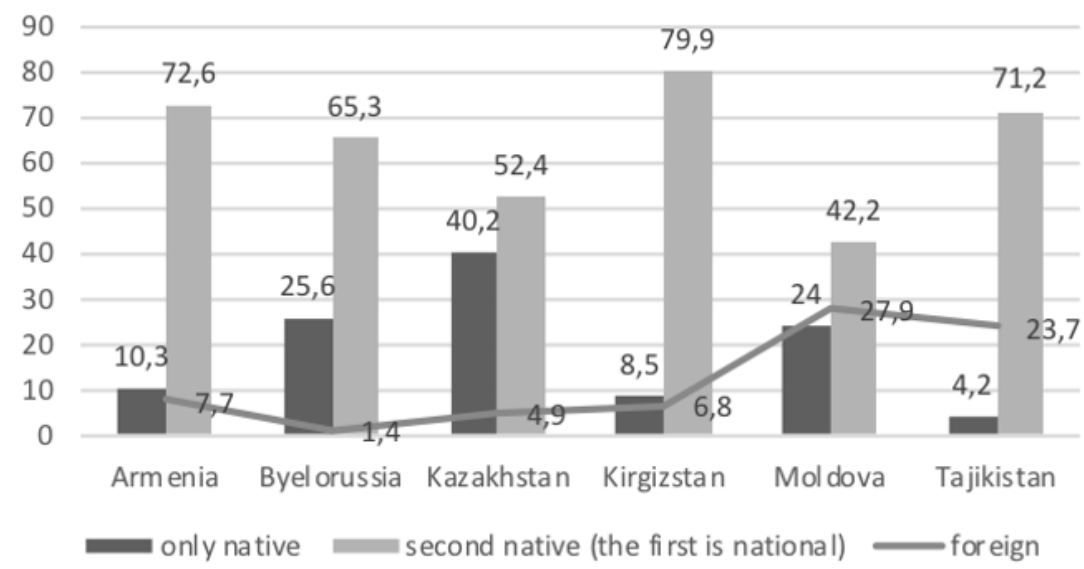

Fig. 1. Distribution of answers of the CIS citizens to the questions: 'Which language for you is the Russian one?' in countries of residence, $\%$. 
We estimated problems, related to the knowledge of languages. Initially, we asked about the first studied in the childhood language and still understood. Revealed $38.7 \%$ of population of the post-Soviet countries who studied Russian first, $14.4 \%$ studied several languages, including Russian, and $46.9 \%$ studied several languages excluding Russian. As for the country specifics in the learning of languages, we may fix $80.2 \%$ of the Byelorussia citizens who learned only Russian in the childhood; $73.7 \%$ of the Tajikistan citizens, $66.1 \%$ - of the Kyrgyzstan and 51.5\% citizens of the Moldova studied other languages in the childhood, excluding Russian. However, 22.5\% citizens of the Armenia studied several languages, including the Russian one.

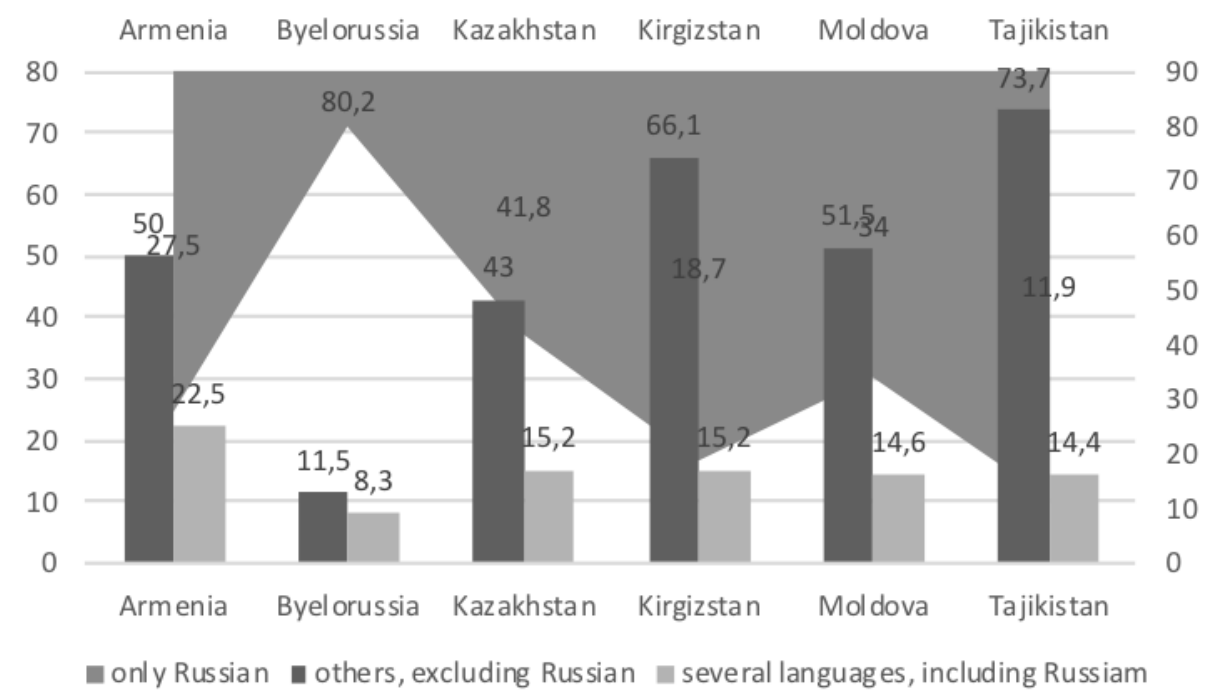

Fig. 2. Distribution of answers of the CIS citizens to the questions: 'Which language did you learn in the childhood and still understand?' in countries of residence, $\%$.

The CIS citizens speak only in Russian in families in $44.8 \%$ of cases, in $45.3 \%$ of cases - use other languages, and in $9.9 \%$ of cases - speak several languages, including the Russian one.

We covered, that the Kazakhstan and Byelorussian citizens in most cases speak Russian in families (53.7\% and $96.3 \%$ correspondingly), in the Moldova republic $36.1 \%$ speak Russian in families, in the Armenia - 26.7\%, in the Kyrgyzstan - 22.5\%, and in the Tajikistan - only $9.3 \%$ of respondents. Correspondingly, in most cases the CIS citizens use national languages in families: in the Tajikistan 78\%, further follows the Armenia (61.7\%), the Moldova (58.5\%), the Kyrgyzstan (58.1\%), the Kazakhstan (37.4\%), and the Byelorussia (1.4\%).

In fact, in most cases in their families the citizens of the CIS countries speak native languages, in some countries - only in native languages and no any others: the Tajikistan (78\%), the Armenia (61.7\%), the Moldova (58.5\%), the Kyrgyzstan, the Kazakhstan (37.4\%), and the Byelorussia (1.4\%) (Fig. 3). 


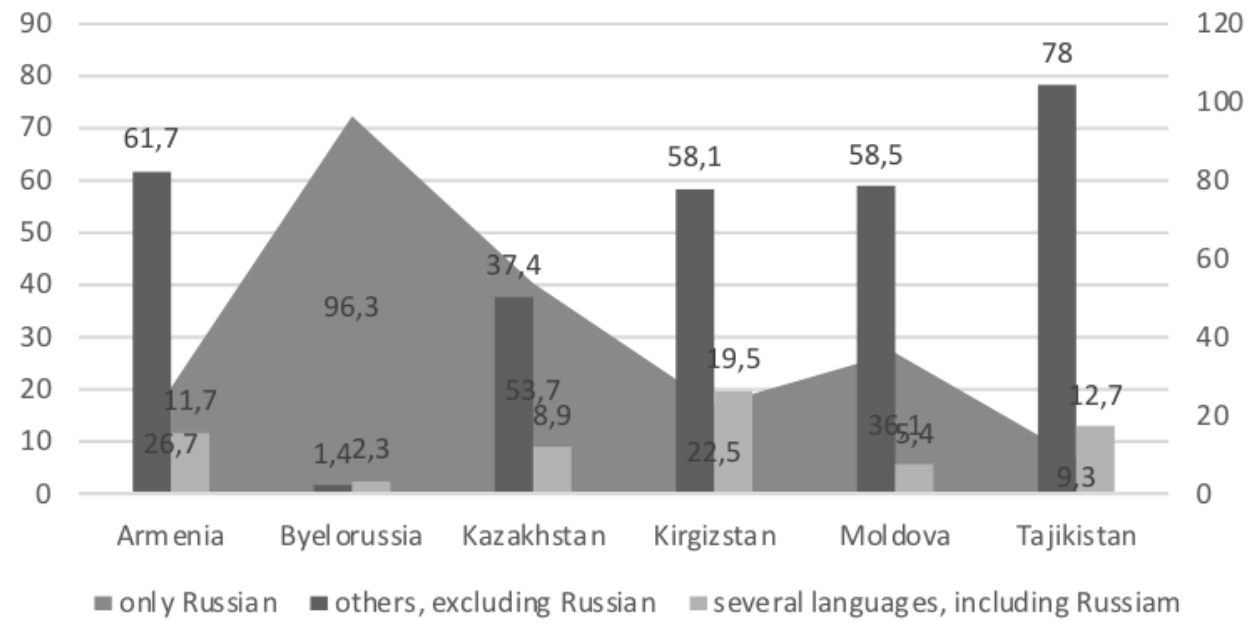

Fig. 3. Distribution of answers of the CIS citizens to the questions: 'Which language do you speak in family?' in countries of residence, $\%$.

Russian language as a language of international communication keeps own positions in public areas. The CS population in $52.4 \%$ of cases use Russian language in public areas and $30.4 \%$ - several languages, including the Russian, and only $17.1 \%$ of the CIS residents speak other languages.

The most used in public spaces are the Russian and other language, including Russian. Thus, in the Byelorussia $93.6 \%$ and $1.4 \%$ of respondents marked these variants, correspondingly; further goes the Tajikistan there $62.7 \%$ of people speak Russian in public areas, and others, including Russian $-23.7 \%$; $54.1 \%$ and $32.5 \%$ correspondingly in the Kazakhstan; $43 \%$ and $43.7 \%$ in the Kyrgyzstan; $31.7 \%$ and $21.7 \%$ in the Armenia, and $23.3 \%$ and $43.7 \%$ in the Moldova (Fig. 4).

Thus, there is evident tendency to preserve the priority of Russian in public spaces of the CIS countries.

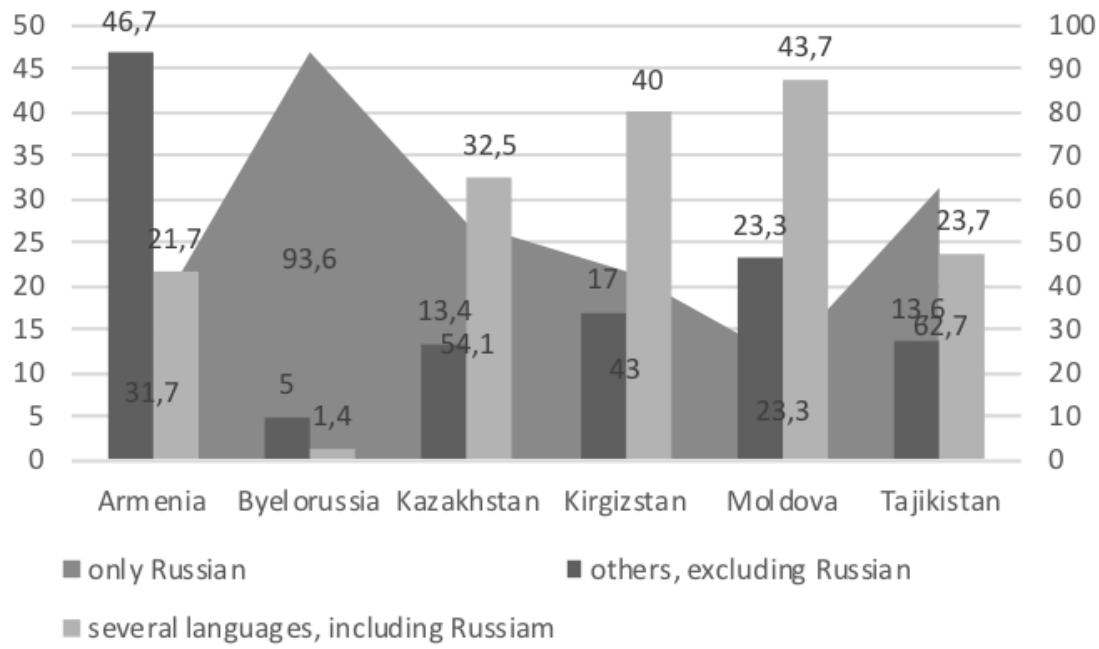

Fig. 4. Distribution of answers of the CIS citizens to the questions: 'Which language do you speak in public spaces?' in countries of residence, $\%$. 
The most part of respondents in the CIS countries (69.2\%) evaluate of language skills in Russian as advanced, i.e. they read original Russian literature, may understand fast speech and able to support discussion. $24.6 \%$ of respondents evaluate own level in Russian as average, i.e. they understand the most part of the speech, ably to communicate about certain themes, but make mistakes sometimes; $4.9 \%$ of the CIS residents are the initial stage of learning Russian, i.e. able to understand slow clear speech, speak by simple phrases and able to communicate on everyday themes.

We revealed an interesting peculiarity in language skills in different countries: in the Tajikistan the most weak level of the Russian, 54.3\% estimated own language skills as average and $18.1 \%$ are at the initial stage of learning, and only $27.6 \%$ of the Tajiks are advanced in the Russian.

In the Moldova Republic, $61.6 \%$ of citizens have an advanced level, $29.1 \%$ - average level and 5.9\% - initial. In the Kazakhstan Republic, $64.6 \%$ of citizens have an advanced level, 26.8\% - average level and 4.9\% - initial. In the Kyrgyzstan Republic, $60 \%$ of citizens have an advanced level, 31.9\% - average level and 3.4\% - initial.

The highest level of language skills is in the Byelorussia and Armenia, there $91.8 \%$ and $86.4 \%$ of respondents correspondingly have advanced Russian (Fig. 5).

Thus the index of the language skills if and indicator of preservation and functioning of the Russian language in the territory of the CIS countries, so we fix the safety of the Russian in the Byelorussia in a great extent, and at the average level in the republics of Armenia, Kazakhstan, Kyrgyzstan, Moldova, and, in the less extent, in the Tajikistan.I

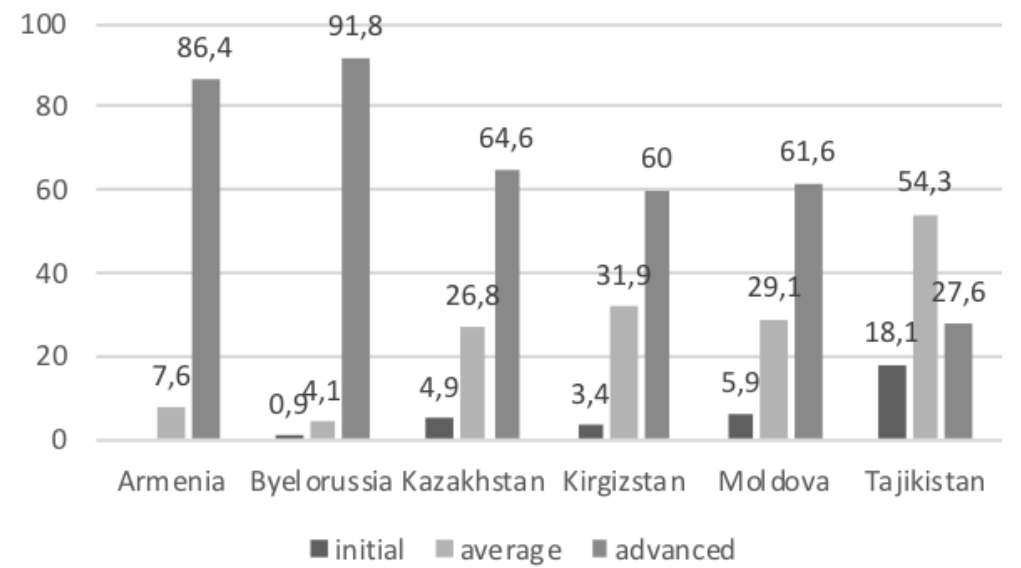

Fig. 5. Distribution of answers of the CIS citizens to the questions: 'How proficient you are in Russian?' in countries of residence, \%.

The popularity of the Russian language in evaluations of the respondents is determined by non-linguistic factors and characteristics and associated by the majority (56\%) of respondents with the successful internal policy by the president Vladimir Putin and development pf economic, trade relations between Russia and other countries $(54.5 \%)$. According to the third part of opinions, development of the tourist sector and attractiveness for the emigration are the significant catalyst of the interest in the Russian language, the influence of target programs, directed on the strengthening of positions of the Russian language and popularization of the Russian culture is not so high and less significant (only $28 \%$ of respondents marked the answer).

Thus, it is important to concentrate attention in promotion and preservation of positions off the Russian language at the post-Soviet space. A great job was done by the Government of the Russian Federation, Russian diplomacy, and institutes of the civil society, occupied 
with questions of distribution of the Russian language abroad. However, the concrete measures on consolidating of positions of the Russian language as one of the world languages, enhancing of demand for the Russian, including the perfection of mechanisms of interaction between Russian governmental bodies and structures of compatriots abroad are necessary.

Paper is prepared in the frameworks of the President's Grant for state support of the leading scientific schools YI-6535.2018.6 'Social risks and security in conditions of transformation of migration processes in the Russian-Asian borderlands' (2018-2019).

\section{References}

1. Migration as a Development Challenge: Analysis of Root Causes and Policy Implications (2017)

2. S. Kobzar, T. Hellgren, S. Hoorens, D. Khodyakov, O. Yaqub, Global Societal Trends to 2030. Thematic Report, 4 (2015)

3. FAO. Addressing the root causes of migration and harnessing its potential for development (2016). M. Denisenko, O. Chudinovskih, Demoskop Weekly Nov., 26 Dec., 9, 533 - 534 (2012) (in Russian)

4. UNICEF. Migration and Youth: Challenges and Opportunities, (2014)

5. H. De Haas, International Migration, 50, 3, 8-25 (2012)

6. I.G. Zhivotovskaya, Globalization as a factor of social transformations in contemporary world (INION RAN, Moscow) 128-180, (2012) (in Russian)

7. S.G. Maximova, G.S. Avdeeva, M.B. Maksimov, Altai State Agrarian University Bulletin, 11, 123-127 (2013)

8. Paper by the Ministry of Internal Affairs of the Russian Federation "Russian language in the world", http://www.mid.ru/foreign_policy/humanitarian_cooperation//asset_publisher/bB3NYd16mBFC/content/id/493778 (2003)

9. S.G. Maximova, O.E. Noyanzina, D.A. Omelchenko, G.S. Avdeeva, M.B. Maximov, International Journal of Environmental and Science Education, 11, 4885-4893 (2016)

10. S.V. Ryazancev, A.A. Grebenyuk, «Our people abroad». Russians, Russian-speaking, compatriots: distribution, integration and return migration to Russia, 238 (2014)

11. Results of the population census in the CIS countries (stage 2002) (2006) 